\begin{tabular}{ccc}
\hline International Journal of Engineering \& Technology, $7(4.38)(2018)$ 140-144 \\
SPC \\
Website www.sciencepubco.com/index.php/IJET \\
Research paper
\end{tabular}

\title{
Peculiarities of a Land Plot Legal Status as an Item of Immovable Property
}

\author{
Olga Vladimirovna Efimova ${ }^{1}$, Olga Sergeevna Smagina ${ }^{2}$, Renata Romanovna Lenkovskaya ${ }^{2}$, Alla Andreevna \\ Neznamova ${ }^{2}$, Maria Aleksandrovna Volkova ${ }^{2}$
}

${ }^{1}$ Moscow City Pedagogical University, Malaya Pirogovskaya Street, 1/1, Moscow, Russian Federation, 119435

${ }^{2}$ Russian State Social University, Wilhelm Pieck Street, 4/1, Moscow, Russian Federation, 129226

\begin{abstract}
The article reviews attributes of immovable things, a land plot in particular, as a special form of an immovable thing. The authors have analyzed conceptual documents and legal precedents allowing identifying various items of immovable property and correlating them with each other. The article identifies gaps in the land legislation and civil legislation related to incomplete definitions and lack of clearly determined attributes of immovable things. The article reflects the latest changes in legislation characterizing a judicial attribute of any immovable property. Based on the identified attributes, in accordance with the Russian legislation, immovable property is divided into several groups. The authors identify a notion of a land plot as a special type of immovable property, without which the things may not exist and be divided into movable and immovable.
\end{abstract}

Keywords: land plot, artificial land plot, immovable property, subsoil assets, land title registration.

\section{Introduction}

\subsection{Introduction of the Problem}

The notion of a land plot has been changed several times, and yet one thing remains invariable - it is its true inherent characteristic of an immovable thing, nonrenewable and valuable natural resource.

Since a land plot may be a subject of a civil transaction, it does not lose its unique character and remains a limited and nonrenewable natural resource, therefore it is recognized as belonging to the public domain regardless of the personality of its owner. Due to duality of its legal nature, we observe a merger of the civil law discretionary rules related to transactions involving land plots and public law declarative rules in the Land Code of the Russian Federation.

An important problem today is that the norms related to the title to immovable property in the form of buildings and structures have been better developed historically in the Russian law system that those norms related to the land plots. In the USSR, the government owned land plots, and they were excluded from the civil circulation. Within the scope of civil legislation reformation, we suggest introducing the policy of eventual merger of the title to a land plot with the title to items of immovable property situated thereon; hence, these objects will have the same owner, i.e. a land plot owner, and the principle of the common fate of things will be fully translated into reality.

\subsection{Importance of the problem}

Specialists in civil law more than once have raised the issues of legal status of a land plot as an immovable property object. General issues of legal regulation of land-related proprietary relationships were discussed by V.V. Vitryanskiy [1], B.M.
Gongalo [2], D.V. Dobrachev [3], O.M. Kozyr [4], K.I. Sklovskiy [5], S.Y. Starodumova [6], N.Y. Shemetova [7]. B.M. Gongalo [8] and A.E. Zolotareva [9], L.B. Sitdikova [10], S.Y. Starodumova [11], explored the notion of immovable property and immovable things classification.

S.P. Grishaev [12], A.Y. Kolov [13], S.Y. Starodumova [14, 15], S.A. Stepanov [16], N.Y. Shemetova [7] paid special attention to a land plot as a special classifier of immovable things and property rights thereto.

\subsection{Hypotheses and their Correspondence to Research Design}

-We suggest clarifying significant attributes described in the Land Code of the Russian Federation, which allow identifying a land plot as an individually-defined thing, in particular: cadastral number and its date, description of a land plot location specifying its boundaries and area, information about any other objects of immovable property situated on a land plot, their description and cadastral numbers, information about forests, bodies of water, and other natural objects situated on a land plot, category of lands and types of its use, etc.

-We suggest including a separate part into the Civil Code of the Russian Federation containing "Title to Land Plots and Other Natural Objects" chapter. We believe that systematization of immovable property objects will ensure easier navigation in the civil legislation; in particular, we suggest separating norms related directly to land plots, buildings and structures, residential and nonresidential premises.

-We believe that only land plots and parts of subsoil assets represent immovable property. Modern technologies allow moving objects that used to be inseparable from land; therefore, it is advisable to exclude such immovable property attribute as inseparability from land from the civil law, since it is already outdated. 
-We identified a necessity to merge title to a land plot with title to items of immovable property situated thereon.

\section{Methods}

We have used generally accepted scientific, specific scientific and specific legal methods of obtaining knowledge. The used specific legal methods included comparatively legal (applied for examination and analysis of legal norms internal structure), formally legal (external analysis of legal norms has been performed), historically legal (applied for finding of cause and effect relationships in arising and development of legal norms and social relations) methods.

The predictive method was used for forecasting of possible developments in state regulation of land titles as objects of civillaw relationships.

When collecting and summarizing law scientists' opinions and legal cases materials, the analysis and synthesis methods have been used.

The authors mainly applied systemically structural method, which allowed identifying key characteristics of the studied object - a land plot.

\section{Results}

We suppose it is appropriate to clarify that a land plot is a part of the earth surface having unique characteristics listed in the effective legislation in art. 8 of the Federal Law dated Jul-13, 2015 No. 218-FZ "On State Registration of Immovable Property" and allowing recognizing it as an individually defined thing. The main data assisting in a land plot identification as an individuallydefined thing may include: a cadastral number and a date of its issue (or a registration number assigned earlier, or a cadastra number assigned as a result of a land plot allotment or separation), description of a land plot location specifying its boundaries and area (provision of this data is mandatory if a land plot is situated within a zone with special conditions of territory use or within a territory of a cultural heritage site, a specially protected nature conservation area, hunting lands, forestry areas, forest-park), within the limits of a special economic zone, within a territory of advanced social and economic development, regional development zone in the Russian Federation, gambling area), as well as information of other objects of immovable property existence on a land plot, their description and cadastral numbers, information about forests, bodies of water, and other natural objects situated within the limits of a land plot, category of lands, and types of its use.

The norms related to civil-law regulation of transactions involving land plots in the Civil Code of the Russian Federation have to be extended and clarified, whereas the Land Code of the Russian Federation needs to be completed with the conceptual framework and norms related to social relationships involving land plots.

Within the scope of civil legislation reformation, we suggest implementation of phased policy for merger of title to a land plot with title to items of immovable property situated thereon; hence, the same person - a land plot owner, will own these objects therefore, the principle of the common fate of things will be fully translated into reality. We believe that the decision to extend the possibility of simplified registration of immovable property owned by people is correct, since it promotes entering of actual data in Rosreestr (the Federal Service for State Registration, Cadaster and Cartography), the state receives taxes, and individuals' title to immovable property is recognized and its protection is guaranteed.

\section{Discussion}

Adoption of the Russian Constitution in 1993 formalized in legislation the individuals' right to own, use and dispose of the land plots, i.e. made them separate objects of proprietary rights. Article 9 of the Russian Constitution points out that land and other natural resources are utilized and protected in the Russian Federation as the basis of life and activity of the people living in corresponding territories. The state guarantees protection of land plot owners' rights, and freedom to utilize them and to execute various civil-law contracts involving lands that are not expropriated or restricted for circulation.

A land plot notion has been changed on numerous occasions in the laws and regulations of the Russian Federation. The attempts to set forth this definition were made within the scope of the Civil Code of the Russian Federation and the Land Code of the Russian Federation.

A land plot notion is contained in part 3 art. 6 of the Land Code of the Russian Federation, it means an immovable thing, a part of ground surface having characteristics making it an individually determined thing. If compared to previous legal definitions or suggestions of the Russian legal experts, this definition sounds abstract, because it does not list the exact characteristics that allow identifying and individually determined thing. We suppose it would have been advisable to clarify that a land plot is a part of ground surface having unique characteristics described in the effective legislation in art. 8 of the Federal Law dated Jul-13, 2015 No. 218-FZ "On State Registration of Immovable Property", which allow identifying it as an individually determined thing. The main data ensuring identification of a land plot as an individually determined thing may include: a cadastral number and a date of its issue (or a registration number assigned earlier, or a cadastral number assigned as a result of a land plot allotment or separation), description of a land plot location specifying its boundaries and area (provision of this data is mandatory if a land plot is situated within a zone with special conditions of territory use or within a territory of a cultural heritage site, a specially protected nature conservation area, hunting lands, forestry areas, forest-park), within the limits of a special economic zone, within a territory of advanced social and economic development, regional development zone in the Russian Federation, gambling area), as well as information of other objects of immovable property existence on a land plot, their description and cadastral numbers, information about forests, bodies of water, and other natural objects situated within the limits of a land plot, category of lands, and types of its use.

Art. 130 of the Civil Code of the Russian Federation gives an example of an immovable thing in the form of a land plot and refers to the Land Code of the Russian Federation, which in turn in its cl. 3 art. 3 defines that proprietary relationships, a land plot owner's proprietary rights, including those related to transactions fulfillment, are regulated by the Civil Code of the Russian Federation, unless otherwise stipulated by special laws; here, we see the duality of proprietary relationships legal regulation by the acts that are not specialized in this field.

Objects included in the notion of "immovable property" or "real estate" have a special place among the civil circulation objects. To recognize the civil circulation objects as immovable property, we have to determine the attributes of such object. Combination of these attributes allows identifying criteria for object allocation both to a generic type, i.e. its recognition as immovable property, and to a certain type of immovable property.

Article 130 of the Civil Code of the Russian Federation points out that legislators recognize land plots, parts of subsoil assets, buildings, structures, objects of incomplete construction, and other objects inseparable from land, which cannot be moved without incommensurate detriment to their intended purpose, as belonging to immovable objects [17]. It should be noted that this attribute is not accurate, since modern technologies allow moving buildings and structures. The article also includes aircrafts, sea vessels, and inland vessels into the incomplete list of immovable things, which is rather conventional, since these items of immovable property objectively do not comply with the criterion of inseparability from the land plot. 
Based on their structure, the items of immovable property are divided into simple and complex. It should be noted that it is difficult to classify things based on this criterion, since the Civil Code of the Russian Federation does not state what piece of immovable property may be recognized as a simple or complex thing. The legislator does not clarify whether a land plot with a house on it belonging to the same owner is a simple thing, or this object may be recognized as a complex thing if the owners of land and house are different persons, and the common fate of a land plot and the building erected on it has been split.

A special example is a unified immovable complex (the UIC) representing a combination of buildings, structures, and other things united by their common purpose and inseparably connected physically or technologically. The UIC includes transportation, communications and utilities lines, e.g. powerlines, and even objects situated on another land plot. Legislator provides a possibility to register title to several non-adjacent land plots, if they jointly represent a UIC.

A land plot is a natural object of immovable property, a complex thing; and restriction of its ability to circulate depends on a category of land. Therefore, the Land Code of the Russian Federation does not contain a clear notion of a land plot as an individually determined thing, with criteria of its determination allowing identifying a land plot as an individual object of immovable property. We suggest expanding art. 6 of the Land Code with cl. 4 listing such criteria and based on art. 8 of the Federal Law dated Jul-13, 2015 No. 218-FZ "On State Registration of Immovable Property".

The Civil Code of the Russian Federation should also contain a provision stating that the title to a land plot is limited to its intended purpose, and ecological and environmental requirements, construction, city planning and fire protection norms, as well as public easement sometimes.

Accounting for the natural peculiarities of a land plot, we suggest expanding the Civil Code of the Russian Federation and the Land Code of the Russian Federation with the provisions related to obtaining of title to artificial (alluvial) and natural (change of a riverbed, shallowing, hydraulic deposition of soil) increase of a land plot. In case of artificial increase of a land plot, legislator must provide that the owner of a land plot should have a permit to perform these actions and then apply for cadastral operations fulfilment and submit an application accompanied with the cadastral operations deliverable (delimitation plan) to Rosreestr for change of a land plot limits. We suggest taking art. 43 of the Federal Law "On State Registration of Immovable Property" as a model and specify that in case of a land plot limits change through their natural increase, plot limits have to be updated. The owner should contact a cadastral engineer, and the latter should perform cadastral operations, the results of which should be entered in the unified electronic information resource related to immovable property - the Unified State Register of Immovable Property (EGRN).

Cl. 4.1. art. 1 of the Federal Law dated Jul-24, 2007 No. 221-FZ

"On Cadastral Activities" points out that the objects of immovable property are land plots, buildings, structures, facilities, objects under construction and parts of land plots, buildings, structures, facilities, and other objects. Thus, this Federal Law does not contain the complete list of objects of immovable property either. Based on the above examples, we may come to conclusion that the legislator preferred not to define this notion accounting for complex specific nature of the objects of immovable property, and that the legislator keeps the list of objects of immovable property open, which causes many theoretical and practical disputes.

It should be noted that the legislator recognizes a notion of an immovable thing as belonging to objects of the right in things; hence, the attributes characterizing this object of the right in things apply to immovable property, namely: physical attribute; economic attribute; legal attribute. These attributes are universal and may be used for identification of all things that are objects of proprietary rights.
When identifying a thing as immovable property, we should remember that immovable property has specific attributes. These attributes may be divided into several groups: based on the nature of their origin; based on characteristics of objects of immovable property; based on their tradability.

Based on the nature of origin, items of immovable property are divided into the following groups: natural (land plots, parts of subsoil assets) cl. 1 art. 130 of the Civil Code of the Russian Federation; and manmade (buildings, structures). At the same time, it should be specifically noted that an artificial land plot, being a manmade object of immovable property, after its commissioning, acquires status of a land plot being a natural object [6].

Having analyzed the wording suggested by the legislator, we may come to conclusion that a land plot is an individually defined thing characterized by existence of peculiar attributes. In addition to a land plot limits, S.Y. Starodumova includes also natural, anthropogenic, and actual (physical) characteristics into the list of these attributes [14].

A.Y. Kolov suggests recognizing natural objects as natural characteristics, namely: soil layer of the earth, trees and shrubs, and isolated bodies of water [13].

The concept for development of civil legislation on immovable property contains a suggestion to exclude forests and bodies of water from the list of the objects of immovable property and grant them the status of land plot attributes, which we consider advisable and simplifying legal regulation of these objects.

Cl. 2 art. 261 of the Civil Code of the Russian Federation states that the title to a land plot covers surface (soil) layer, bodies of water and plants situated within the established limits of a certain plot. It should be noted that the Land Code of the Russian Federation does not mention any natural characteristics, which we see as legislator's negligence.

Anthropogenic characteristics should include manmade buildings, structures, and facilities inseparable from a land plot, which jointly form a complex thing (art. 134 of the Civil Code of the Russian Federation). Pursuant to cl. 5 art. 1 of the Land Code of the Russian Federation, the fate of the main thing (a land plot) may not be changed without changing the fate of objects inseparable therefrom (a building situated on a land plot; melioration system, etc.). A special case is an artificial land plot created on a body of water: it is a structure created on a body of water or its part using soil dumping or hydraulic deposition of soil, or any other technology, which is recognized as a land plot after its commissioning. This type of immovable property is special since it belongs to the category of natural land plots regardless of anthropogenic nature of its creation.

It should be noted that often immovable things having anthropogenic characteristics are not only complex but compound too, i.e. consisting of a combination of immovable things (e.g. a soccer pitch or a unified immovable complex).

A physical attribute expresses actual existence of a land plot within the established limits, area, and coordinates representing a part of individually identified earth surface in the territory of the Russian Federation. B.M. Gongalo in his article "Notion of Immovable Property" expresses opinion that immovable property is solely a physical notion [8]. Based on this definition, the author concludes that immovable property is any object meeting the definition offered by the legislator, even if such object is not registered. Since the Land Code of the Russian Federation and the Civil Code of the Russian Federation do not provide an exhaustive list of immovable things, the scientist thinks that any objects having attributes of immovable property identified by the law are immovable property in fact.

N.Y. Shemetova believes that immovable property only means a land plot and objects that are organically inseparable from it, individually identified in-situ, which lose their purpose when separated from land [7].

In our opinion, both authors ignore a legal attribute of immovable thing, namely recognition of a certain land plot by state, setting 
forth its legal status, and enforcing its legal protection from thirdparty claims.

From our point of view, only land plots and parts of subsoil assets represent immovable property. Modern technologies allow moving objects that used to be inseparable from land. One way or another, the other items of immovable property are a legal fiction specified by the legislator as immovable things based on a number of factors (including economic and political) in order to make legal norms uniform.

Legal attribute means that the state recognizes a land plot as an immovable thing, object of proprietary rights and puts it into the category of lands (designation) and performs state registration of a land plot as immovable property. According to art. 130 of the Civil Code of the Russian Federation and cl. 3 art. 1 of the Federal Law "On State Registration of Immovable Property", a land plot is immovable property by its nature, whether it is registered or not The Supreme Court of the Russian Federation in its decision dated August 4, 2016 No. 4-АПГ16-11 pointed out that absence of land title registration does not prevent performing of state cadastral evaluation [18]. Mr. V. filed an appeal to the Supreme Court of the Russian Federation asking to repeal the order of the Ministry of Ecology and Natural Resources Management of Moscow Area dated November 26, 2013 No. 564-PM "On Approval of the Results of State Cadastral Evaluation of Lands Belonging to Horticultural, Market-Gardening, and Dacha Associations, and Land Plots Designated for Horticulture, Gardening, and Dacha Development (Construction) in the Territory of Moscow Area". Mr. V. owned a land plot, allotted 403 land plots out of it, but didn't manage to register the title to the newly allotted land plots in time and in accordance with the procedure established by law, whereas the Ministry of Ecology and Natural Resources Management of Moscow Area issued the order to assign these land plots to Voskresenskiy Municipal Region. The owner, $\mathrm{Mr}$ $\mathrm{V}$., believes that this order is unlawful, since at the time of evaluation results approval and entering into the state cadaster of immovable property, the title to these land plots has not been registered in accordance with the procedure established by law, and the cadastral value of the created land plots results in payment of higher tax on land.

Based on the summary of court rulings, we suggest expanding the Civil Code of the Russian Federation with provisions regulating ownership relations when dividing a land plot into several new plots and when forming a new land plot by merger of several plots owned by the same person.

The academic lawyers are arguing whether the existence of legal attribute of an immovable thing is dependent on the necessity of land plots' state registration. Scientists K.I. Sklovskiy and B.M. Gongalo hold to directly opposite opinions. K.I. Sklovskiy in his monography gives examples of court decisions supporting the necessity of state acknowledgement and, therefore, legal protection of the immovable property objects. He points out that only registered land plots are involved in civil circulation [5]. B.M. Gongalo thinks that immovable property is not a legal but physical notion; therefore, the fact of state registration does not have any material impact on the fact of immovable things existence [2].

State registration of title to a land plot is expressed in state acknowledgement of arising, limitation (encumbrance), transfer, or termination of title to a land plot. This legal act certifies the owner's rights and protects them from third-party infringements. For this purpose, legislator has developed unified informational electronic register (EGRN) containing description of the objects of immovable property and information about the title thereto [15] Pursuant to art. 18 of the Federal Law "On State Registration of Immovable Property", the same agency will perform cadastral registration and state registration of rights to immovable property and transactions therewith - the Federal Service for State Registration, Cadastral Records and Cartography (Rosreestr). Before that, two different agencies used to perform cadastral registration and state registration of rights to immovable property
- the Cadastral Chamber and Rosreestr. It used to create significant difficulties in the process and timeframe of registration $[11,19,20]$

V. V. Vitryanskiy believes that cl. 3 art. 3 should be excluded from the Land Code of the Russian Federation, since the provision on legal regulation of proprietary relationships involving ownership, use and disposal of a land plot, as well as execution of transactions therewith, is regulated by the Civil Code of the Russian Federation, unless otherwise stipulated by the Land Code of the Russian Federation, the Water Code, the Forestry Code, the Federal Law "On Subsoil Assets", or other laws and regulations, which, in the scientist's opinion, unreasonably expands the sphere of the Land Code application through proprietary relationships representing the subject matter of civil law regulation [1]. We believe that legal provisions of the Civil Code of the Russian Federation related to civil law regulation of transactions with the land plots have to be expanded and clarified, whereas the Land Code of the Russian Federation needs to be completed with definitions and norms related to social relationships involving land plots. Regardless of legal relations, in which a land plot is involved as the subject matter, essentially, it is a special natural resource, and the key task of the government is to protect it. Hence, governmental control of compliance with the legislation has to be stricter, and field inspections have to be performed more often $[21,22,23]$. Environmental law rules have to be more than declarative, and the level of individuals' legal consciousness and care for such valuable resource as a land plot should be brought up through governmental educative activities in the field of environment protection.

In the Russian law, historically, the rules related to the title to immovable property in the form of buildings and structures have been developed better that those related to land plots. In the USSR, land plots were owned by state and were excluded from civil circulation [16]. Therefore, we still may face a situation when the title to a building is legalized, unlike the title to a land plot.

Although a land plot may be a subject matter of a civil transaction, it does not lose its unique character and remains a limited and nonrenewable natural resource; therefore, it is recognized as belonging to the public domain regardless of the personality of its owner. Due to duality of its legal nature, we observe a merger of the civil law discretionary rules related to transactions involving land plots and public law declarative rules in the Land Code of the Russian Federation.

In opinion of S.P. Grishaev, a different legal status applies to civil transactions with land plots, and often the legal rules violate principle of art.1 of the Land Code of the Russian Federation related to the common fate of a thing, i.e. that of a land plot and immovable property situated thereon. The scientist believes that the principle of the common fate of a land plot declared in the Land Code of the Russian Federation is of declarative nature, it is non-enforceable within the scope of modern legislation, and it represents a remote prospect of civil law development in Russia [12].

Art. 1 of the Land Code of the Russian Federation is of declarative nature, and its principle of the common fate of a thing, i.e. a land plot and inseparable objects of immovable property, is hard to enforce. Today, the problem is that when regulating relationships of title to a land plot and buildings or structures, and other objects of immovable property situated thereon, and their civil circulation, legislator looks at them from two points of view: they are seen as immovable objects, which may independently participate in civil circulation, and they are seen as physically and legally bound types of immovable property [4].

\section{Conclusion}

Due to the above, within the scope of civil legislation reformation, we suggest introducing the policy of eventual merger of the title to 
a land plot with the title to items of immovable property situated thereon; hence, these objects will have the same owner, i.e. a land plot owner, and the principle of the common fate of things will be fully translated into reality.

"The Concept of Civil Legislation Development in the Russian Federation" suggests amending the Civil Code of the Russian Federation and comprising the norms related to the right of ownership (title) in a separate chapter "Title to Land Plots and Other Natural Objects". We believe that systematization of immovable property objects will ensure easier navigation in the civil legislation; in particular, we suggest separating norms related directly to land plots, buildings and structures, residential and nonresidential premises.

\section{References}

[1] V.V. Vitryanskiy, Pravovoe regulirovanie imushchestvennykh otnosheniy $\mathrm{v}$ Zemelnom kodekse RF [Legal Regulation of proprietary Relationships in the Land Code of the Russian Federation], Khozyaystvo i parvo 7 (2010).

[2] B.M. Gongalo, Sdelki s nedvizhimost'yu v kommercheskom oborote [Transactions with Immovable Property in Commercial Circulation], Wolters Kluwer, Moscow, 2006.

[3] D.V. Dobrachev, Problemy sudebnoy praktiki v sfere oborota zeml [Problems of Court Rulings Related to Land Plots Circulation], Wolters Kluwer, Moscow, 2005.

[4] O.M. Kozyr, A.A. Makovskaya, Puti sovershenstvovaniya pravovogo regulirovaniya oborota nedvizhimosti [The Ways to Perfect Legal Regulation of Immovable Property Circulation], Vestnik VAS RF 2 (2003) 110

[5] K.I. Sklovskiy, Sobstvennost v grazhdanskom prave [Ownership in Civil Law], Moscow, 2010.

[6] S.Y. Starodumova, Obyazatelstva po okazaniyu gosudarstvennykh uslug v zemelno-imushchestvennykh otnosheniyakh [Obligations for State Services Rendering in Land and Property Relations] Aktualnye problemy rossiyskogo zakonodatelstva 10 (2015) 91-97.

[7] N.Y. Shemetova, Opredelenie nedvizhimogo imushchestva v Rossii: ekonomicheskie predposylki i pravovye podkhody [Definition of Immovable Property in Russia: Economic Rationale and Legal Approaches], Imushchestvennye otnosheniya $\mathrm{v}$ Rossiyskoy Federatsii 7 (2014).

[8] B.M. Gongalo, Ponyatie nedvizhimosti [The Notion of Immovable Property], EZh-Yurist 11 (2001)

[9] A.E. Zolotareva, S.J. Starodumova, A.A. Neznamova, R.R Lenkovskaya, M.A. Volkova, Land Plots as a Variety of Immovable Things, Journal of Advanced Research in Law and Economics 7(29) (2017). DOI: http://dx.doi.org/10.14505/jarle.

[10] L.B. Sitdikova, A.A. Neznamova, M.A. Volkova, S.J. Starodumova, R.R. Lenkovskaya, Establishment of rights to consolidated real estate complex, Man in India 97(22) (2017) 135145.

[11] S.Y. Starodumova, Problemy teorii i praktiki priobreteniya prava sobstvennosti na zemelnye uchastki, raspolozhennye pod obektami zhilishchnogo stroitelstva [Theoretical and Practical Problems Related to Obtaining of Title to Land Plots Situated under the Residential Construction Objects], Notarius 3 (2009) 12-15.

[12] S.P. Grishaev, Grazhdansko-pravovoy rezhim zemelnykh uchastkov [Civil-Law Status of Land Plots], Tsivilist 4 (2006).

[13] A.Y. Kolov, Veshchnye prava na zemelnyy uchastok v Rossi [Proprietary Rights to a Land Plot in Russia], Peleng, Tomsk, 2004.

[14] S.Y. Starodumova, K voprosu o priznakakh nedvizhimykh veshchey [The Issue of Immovable Things' Attributes], Aktualnye problemy rossiyskogo zakonodatelstva 8 (2014) 117-127.

[15] S.Y. Starodumova, Ponyatie i vidy nedvizhimykh veshchey v grazhdanskom prave [The Notion and Types of Immovable Things in the Civil Law], Biznes v zakone 3 (2015) 52-55.

[16] S.A. Stepanov, Nedvizhimoe imushchestvo v grazhdanskom prave [Immovable Property in the Civil Law], Statut, Moscow, 2004.

[17] V.A. Malcev, G.N. Kuleshov, A.A. Neznamova, N.V. Lutovinova, A.A. Guryleva, Civil liability insurance of vehicle owners in European Union countries and the Russian federation: Comparative legal analysis, Man in India 96(12) (2016) 5565-5574.

[18] P.V. Zhesterov, A.A. Neznamova, S.J. Starodumova, M.A Volkova, R.R. Lenkovskaya, The Legal Regime of the Deliverables under the Appraisal Contract, Man in India 97(25) (2017) 357-364.
[19] A.Y. Svirin, A.A. Mokhov, V.A. Gureev, S.N. Shestov, A.L. Shilovskaya, Proof and evidence in cases involving compensation for damage caused to health or life of a citizen as a result of the use of drugs for medical use, Journal of Advanced Research in Law and Economics, VIII, Spring, 1(23) (2017) 250-260. DOI: 10.14505/jarle.v8.1(23).28

[20] A.L. Shilovskaya, S.J. Starodumova, M.A. Volkova, P.V Zhesterov, The judicial practice of the European Court in the sphere of non-material reputational harm, Man in India 96(12) (2016) 5635-5645

[21] N.V. Lutovinova, A.A. Neznamova, A.A. Guryleva, O.G. Bolshakova, D.V. Shmyrev, Fundamental legal principles for implementation of state control over land use in the Russian Federation, Journal of Advanced Research in Law and Economics 5(2) (2014) 136-146

[22] N.V. Lutovinova, A.A. Neznamova, G.N. Kuleshov, V.A. Bulaev, D.V. Shmyrev, The role of appraisal services when carrying out the state control over the use of land in the Russian Federation, Journal of Internet Banking and Commerce 21(Special Issue 6) (2016).

[23] A.V. Ryzhik, L.V. Glazkova, N.V. Lutovinova, A.E. Zolotareva, A.A. Guryleva, The content of protection of citizens' proprietary rights to the land plots in the Russian Federation as an issue for debate, Man in India 97(25) (2017) 131-140. 